\title{
Front Matter: Volume 9184
}

, "Front Matter: Volume 9184," Proc. SPIE 9184, Organic Photovoltaics XV, 918401 (11 November 2014); doi: 10.1117/12.2087632

SPIE Event: SPIE Organic Photonics + Electronics, 2014, San Diego, California, SPIE. United States 


\section{PROCEEDINGS OF SPIE}

\section{Organic Photovoltaics XV}

Zakya H. Kafafi

Paul A. Lane

Ifor D. W. Samuel

Editors

\section{9-21 August 2014}

San Diego, California, United States

Sponsored by

SPIE

Cosponsored by

Aldrich Materials Science (United States)

Polyera Corporation (United States)

Published by

SPIE 
The papers included in this volume were part of the technical conference cited on the cover and title page. Papers were selected and subject to review by the editors and conference program committee. Some conference presentations may not be available for publication. The papers published in these proceedings reflect the work and thoughts of the authors and are published herein as submitted. The publisher is not responsible for the validity of the information or for any outcomes resulting from reliance thereon.

Please use the following format to cite material from this book:

Author(s), "Title of Paper," in Organic Photovoltaics XV, edited by Zakya H. Kafafi, Paul A. Lane, Ifor D. Samuel, Proceedings of SPIE Vol. 9184 (SPIE, Bellingham, WA, 2014) Article CID Number.

ISSN: 0277-786X

ISBN: 9781628412116

Published by

SPIE

P.O. Box 10, Bellingham, Washington 98227-0010 USA

Telephone +1 3606763290 (Pacific Time) · Fax +1 3606471445

SPIE.org

Copyright (C) 2014, Society of Photo-Optical Instrumentation Engineers.

Copying of material in this book for internal or personal use, or for the internal or personal use of specific clients, beyond the fair use provisions granted by the U.S. Copyright Law is authorized by SPIE subject to payment of copying fees. The Transactional Reporting Service base fee for this volume is $\$ 18.00$ per article (or portion thereof), which should be paid directly to the Copyright Clearance Center (CCC), 222 Rosewood Drive, Danvers, MA 01923. Payment may also be made electronically through CCC Online at copyright.com. Other copying for republication, resale, advertising or promotion, or any form of systematic or multiple reproduction of any material in this book is prohibited except with permission in writing from the publisher. The CCC fee code is $0277-786 \mathrm{X} / 14 / \$ 18.00$.

Printed in the United States of America.

Publication of record for individual papers is online in the SPIE Digital Library.

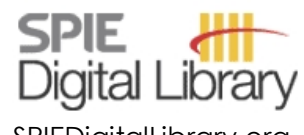

SPIEDigitalLibrary.org

Paper Numbering: Proceedings of SPIE follow an e-First publication model, with papers published first online and then in print and on CD-ROM. Papers are published as they are submitted and meet publication criteria. A unique, consistent, permanent citation identifier (CID) number is assigned to each article at the time of the first publication. Utilization of CIDs allows articles to be fully citable as soon as they are published online, and connects the same identifier to all online, print, and electronic versions of the publication. SPIE uses a six-digit CID article numbering system in which:

- The first four digits correspond to the SPIE volume number.

- The last two digits indicate publication order within the volume using a Base 36 numbering

system employing both numerals and letters. These two-number sets start with 00, 01, 02, 03, 04, $05,06,07,08,09,0 A, 0 B \ldots$. OZ, followed by 10-1Z, 20-2Z, etc.

The CID Number appears on each page of the manuscript. The complete citation is used on the first page, and an abbreviated version on subsequent pages. Numbers in the index correspond to the last two digits of the six-digit CID Number. 


\section{Contents}

$\checkmark$ Authors

vii Conference Committee

ix Direct electronic probing of biological complexes formation (Organic Photonics + Electronics Plenary Paper) [9183-402]

NOVEL DONORS AND ACCEPTORS FOR ORGANIC PHOTOVOLTAICS

918408 Cyanine dyes in solid state organic heterojunction solar cells (Invited Paper) [9184-5]

9184 OC Solution-processable perylene diimide based star-shaped small molecule acceptor: synthesis and photovoltaic properties [9184-9]

CHARGE TRANSFER AT THE ORGANIC HETEROJUNCTION II: JOINT SESSION WITH CONFERENCES 9165 AND 9184

9184 OG Hot photocarrier dynamics in organic solar cells measured by transient absorption and time-resolved terahertz spectroscopy (Invited Paper) [9184-12]

HYBRID SOLAR CELLS WITH ORGANIC AND INORGANIC COMPONENTS

9184 OR High efficiency porphyrin sensitized mesoscopic solar cells (Invited Paper) [9184-23]

IMPORTANCE OF ORDER AND MORPHOLOGY IN ORGANIC SOLAR CELLS

$9184 \mathrm{OZ}$ Correlating domain purity with charge carrier mobility in bulk heterojunction polymer solar cells (Invited Paper) [9184-31]

SCALING ORGANIC PHOTOVOLTAICS FROM CELLS TO MODULES

918415 Organic solar cells: from lab to roll-to-roll production (Invited Paper) [9184-37]

918418 Solution processed flexible planar hybrid perovskite solar cells [9184-40]

9184 1A Flexible organic tandem solar modules: a story of up-scaling [9184-42] 
9184 ID Semitransparent organic photovoltaic modules with Ag nanowire top electrodes [9184-45]

9184 IE Plasmonic electrodes for organic photovoltaics: polarization-independent absorption enhancement [9184-47]

\section{POSTER SESSION}

$9184 \mathrm{lL}$ Inverted polymer solar cells based on thin ZnO films grown by Mist chemical vapor deposition system [9184-57]

$9184 \mathrm{lP} \quad$ Understanding charge transport in vacuum deposited Schottky organic solar cells with microsecond transient photocurrent measurements [9184-62]

$91841 Q \quad$ Reducing the variability in performance of organic solar cells containing vacuum deposited $\mathrm{MOO}_{\mathrm{x}}$ extraction layers [9184-63]

9184 IT Nanobump assembly for plasmonic organic solar cells [9184-66]

9184 IV Pyrrolidinone derivatives as processing additives for solution processed organic solar cells [9184-68]

$9184 \mathrm{IW}$ Charge dynamics in alkanedithiols-additives in P3HT:PCBM bulk heterojunction solar cells [9184-69]

918422 Multiscale study of the effect of solvent on the glass transition temperature, molecule diffusion, and reorientation of P3HT-PCBM [9184-76]

918423 Holographic spectral beamsplitting for increased organic photovoltaic conversion efficiency [9184-77]

918424 Degradation effects on charge carrier transport in P3HT:PCBM solar cells studied by PhotoCELIV and ToF [9184-78]

918425 Increasing optical density of single-layer multi-polymer bulk-heterojunction OPVs using $\mathrm{CdSe}(\mathrm{ZnS})$ core(shell) quantum dots [9184-79]

918426 Performance improvement of dye-sensitized solar cells by surface patterning of FTO electrodes [9184-80]

9184 2K Photophysics and charge transfer in donor-acceptor triblock copolymer photovoltaic materials [9184-98] 


\title{
Author Index
}

Numbers in the index correspond to the last two digits of the six-digit citation identifier (CID) article numbering system used in Proceedings of SPIE. The first four digits reflect the volume number. Base 36 numbering is employed for the last two digits and indicates the order of articles within the volume. Numbers start with 00, 01, 02, 03, 04, 05, 06, 07, 08, 09, OA, OB...0Z, followed by 10-1Z, 20-2Z, etc.

\author{
Ade, Harald, $\mathrm{OZ}$ \\ Ameri, Tayebeh, 1A \\ Ayala, Silvana, 23 \\ Aziz, Hany, 1P, 1Q, IV \\ Baran, Derya, $1 \mathrm{~A}$ \\ Bartoli, Filbert J., $1 \mathrm{E}$ \\ Biswas, Chandan, $1 \mathrm{~L}$ \\ Brabec, Christoph J., 1A, ID \\ Bump, Buddy J., 25 \\ Cho, Chun-Pei, 26 \\ Choi, Mansoo, $1 \mathrm{~T}$ \\ Cunningham, Paul D., OG \\ Echols, Robert S., 25 \\ Egbe, Daniel A. M., OZ \\ Falkenberg, Christiane, 15 \\ Forberich, Karen, 1D \\ Friedlein, Jacob T., 23 \\ Geiger, Thomas, 08 \\ Genevičius, K., 24 \\ Ghiggino, Kenneth P., 2K \\ Gill, Hardeep Singh, 18 \\ Giordano, Fabrizio, OR \\ Giordano, Francesco, ix \\ Graeff, Carlos F. O., 08 \\ Grätzel, Michael, OR \\ Guo, Fei, 1D \\ Hany, Roland, 08 \\ Heier, Jakob, 08 \\ Heilweil, Edwin J., OG \\ Heimke, Bruno, 15 \\ Hoppe, Harald, $\mathrm{OZ}$ \\ Hou, Jianhui, OC \\ Huang, Min, 22 \\ Jiang, Bo, OC \\ Jiao, Xuechen, $\mathrm{OZ}$ \\ Jones, David J., 2K \\ Jung, Kinam, $1 T$ \\ Juška, G., 24 \\ Kafafi, Zakya H., 1E \\ Karuthedath, S., 24 \\ Kästner, Christian, $\mathrm{OZ}$ \\ Kawaharamura, Toshiyuki, $1 \mathrm{~L}$ \\ Klemet, Matthias, 15 \\ Ko, Youngjun, $1 \mathrm{~T}$ \\ Kokil, Akshay, 18 \\ Kostuk, Raymond K., 23 \\ Kubis, Peter, 1A, 1D \\ Kumar, Jayant, 18 \\ Lam, Yeng Ming, IW
}

\author{
Lane, Paul A., OG \\ Lee, Changhee, $1 \mathrm{~T}$ \\ Lee, Gunhee, $1 \mathrm{~T}$ \\ Lee, Jong-Kwon, $1 T$ \\ Li, Lian, 18 \\ Li, Ning, $1 \mathrm{~A}$ \\ Liu, Manhua, 22 \\ Lucera, Luca, 1A \\ Luscombe, Christine K., 23 \\ Ma, Zhu, IL \\ Macchia, Elenora, ix \\ Machui, Florian, 1A \\ Magliulo, Maria, ix \\ Manoli, Kyriaki, ix \\ Melinger, Joseph S., OG \\ Mosurkal, Ravi, 18 \\ Nüesch, Frank A., 08 \\ Olson, Grant T., 25 \\ Palazzo, Gerardo, ix \\ Pavageau, Bertrand, IV \\ Peng, Chuyao, 08 \\ Pfeiffer, Martin, 15 \\ Przybilla, Thomas, 1D \\ Rabe, Jan, 15 \\ Russo, Juan M., 23 \\ Salvador, Michael, 1 A \\ Savermann, T., 24 \\ Savage, Richard, 25 \\ Schwarz, Kyra N., 2K \\ Servant, Laurent, IV \\ Shaheen, Sean E., 23 \\ Smith, Trevor A., 2K \\ Solanki, Ankur, IW \\ Song, Hyung-Jun, IT \\ Spiecker, Erdmann, 1D \\ Spyropoulos, George D., IA \\ Stephen, M., 24 \\ Sum, Tze Chien, IW \\ Sutty, Sibi, IP \\ Teuscher, Joël, OR \\ Torsi, Luisa, ix \\ Uhrich, Christian L., 15 \\ Véron, Anna C., 08 \\ Vismara, Marcus V. G., 08 \\ Voigt, Monika M., IA \\ Vongsaysy, Uyxing, $1 \mathrm{~V}$ \\ Vorndran, Shelby D., 23 \\ Wang, Kang L., $1 \mathrm{~L}$ \\ Wang, Yu-Chao, 26
}


Wichtendahl, Ralph, 15

Wilde, Christian, 15

Williams, Graeme, 1P, 1Q

Wu, Bo, $1 \mathrm{~W}$

Wu, Yuechen, 23

Yao, Jiannian, OC

Yi, Chenyi, OR

Zakeeruddin, Shaik M., OR

Zeng, Beibei, $1 \mathrm{E}$

Zhan, Chuanlang, OC

Zhang, Shaoging, OC

Zhang, Xin, OC

Zhu, Xiaodan, $1 \mathrm{~L}$

Proc. of SPIE Vol. 9184 918401-6

Downloaded From: https://www.spiedigitallibrary.org/conference-proceedings-of-spie on 25 Apr 2023 Terms of Use: https://www.spiedigitallibrary.org/terms-of-use 


\section{Conference Committee}

Symposium Chair

Zakya H. Kafafi, National Science Foundation, ret (United States)

Conference Chair

Zakya H. Kafafi, National Science Foundation, ret (United States)

Conference Co-Chairs

Paul A. Lane, U.S. Naval Research Laboratory (United States)

Ifor D. W. Samuel, University of St. Andrews (United Kingdom)

Conference Program Committee

Natalie Banerji, Ecole Polytechnique Fédérale de Lausanne

(Switzerland)

Christoph J. Brabec, Friedrich-Alexander-Universität Erlangen-

Nürnberg (Germany)

Paul L. Burn, The University of Queensland (Australia)

Antonio F. Facchetti, Polyera Corporation (United States)

René A. J. Janssen, Technische University Eindhoven (Netherlands)

Bernard Kippelen, Georgia Institute of Technology (United States)

Ana F. Nogueira, University of Campinas (Brazil)

Dana C. Olson, National Renewable Energy Laboratory (United States)

Barry P. Rand, Princeton University (United States)

Sean E. Shaheen, University of Colorado at Boulder (United States)

Jiangeng Xue, University of Florida (United States)

He Yan, Hong Kong University of Science and Technology

(Hong Kong, China)

Yang Yang, University of California, Los Angeles (United States)

Teketel Yohannes, Addis Ababa University (Ethiopia)

\section{Session Chairs}

1 Advances in Organic Photovoltaics

Zakya H. Kafafi, National Science Foundation (United States)

2 Novel Donors and Acceptors for Organic Photovoltaics

Michael L. Chabinyc, University of California, Santa Barbara

(United States) 
3 Charge Transfer at the Organic Heterojunction I: Joint Session with Conferences 9165 and 9184

Barry P. Rand, Princeton University (United States)

4 Charge Transfer at the Organic Heterojunction II: Joint Session with Conferences 9165 and 9184

Paul A. Lane, U.S. Naval Research Laboratory (United States)

Zakya H. Kafafi, National Science Foundation, ret (United States)

5 Charge Separation and Recombination

Thuc-Quyen Nguyen, University of California, Santa Barbara (United States)

6 Hybrid Solar Cells with Organic and Inorganic Components

Ifor D. W. Samuel, University of St. Andrews (United Kingdom)

7 Bulk Heterojunction Organic Solar Cells

Harald Hoppe, Technische University Ilmenau (Germany)

8 Importance of Order and Morphology in Organic Solar Cells

Paul A. Lane, U.S. Naval Research Laboratory (United States)

9 Scaling Organic Photovoltaics from Cells to Modules

Ross Larsen, National Renewable Energy Laboratory (United States)

10 Novel Materials for Electrodes and Interfaces

Sean E. Shaheen, University of Colorado at Boulder (United States)

Paul A. Lane, U.S. Naval Research Laboratory (United States)

Poster Session

Paul L. Burn, The University of Queensland (Australia)

Dana C. Olson, National Renewable Energy Laboratory

(United States) 